\title{
THE EFFECTS OF TEMPERATURE, OSMOLALITY AND HYDROGEN ION CONCENTRATION ON THE ACTIVATION AND ACROSOME REACTION OF GOLDEN HAMSTER SPERMATOZOA
}

\author{
CHERRIE A. MAHI AND R. YANAGIMACHI \\ Department of Anatomy and Reproductive Biology, University of Hawaii \\ School of Medicine, Honolulu, Hawaii 96822, U.S.A.
}

(Received 5th September 1972)

\begin{abstract}
Summary. Golden hamster spermatozoa were incubated in a medium consisting of $50 \%$ Tyrode's solution and $50 \% \gamma$-globulin-free human serum (gas phase, air). The effects of incubation temperatures of 42 to $16^{\circ} \mathrm{C}$ were studied. Sperm activation, acrosome reaction and survival were impaired at $42^{\circ} \mathrm{C}$. Below $42^{\circ} \mathrm{C}$, the time required for activation to occur was inversely proportional to the incubation temperature. Spermatozoa could be activated almost instantly by warming them to $37^{\circ} \mathrm{C}$ following preincubation for 'critical' lengths of time at temperatures of $31^{\circ} \mathrm{C}$ and below. The acrosome reaction reached a maximum level approximately $1 \frac{1}{2} \mathrm{hr}$ after activation at 33 to $40^{\circ} \mathrm{C}$. At 31 to $23^{\circ} \mathrm{C}$, the time increased as lower temperatures were used. Following warming, the acrosome reaction reached its maximum about $3 \mathrm{hr}$ after the critical time. The final percentages of activation and acrosome reaction and the survival rates were not affected between 25 and $40^{\circ} \mathrm{C}$. The possibility that at least three phases or processes are involved in activation and acrosome reaction is discussed.

Osmotic pressures ranging between 193 and 470 mosmol were tested with the best rates of sperm activation, acrosome reaction and survival occurring at 230 to 343 mosmol. The effects of $\mathrm{pH}$ values of $5 \cdot 4$ to 8.6 were tested. Activation, acrosome reaction and survival were best within the range of $7 \cdot 2$ to $7 \cdot 8$. The relationships of the observed $\mathrm{pH}$ and osmotic pressure optima to conditions within the female genital tract are considered.
\end{abstract}

\section{INTRODUCTION}

When hamster epididymal spermatozoa are suspended in a medium capable of inducing capacitation, a distinct series of events can generally be observed. In a mixture of Tyrode's solution and detoxified blood serum, they show an initial burst of activity and soon agglutinate head-to-head. After agglutination, sperm motility is markedly reduced for 1 to $1 \frac{1}{2} \mathrm{hr}$ but with the passage of time, motility steadily increases until spermatozoa begin to break away from the 
agglutinations. About this time, there is a noticeable change in the swimming behaviour of the spermatozoa characterized by vigorous and extreme flexing of the flagella. This is referred to as 'activation' (Yanagimachi, 1970a) and is very different from the initial burst of motility of epididymal spermatozoa which occurs when they are first suspended in an oxygen-rich medium. Soon after the start of activation, many of the spermatozoa lose the anterior segment of the acrosome (acrosomal cap; Yanagimachi \& Noda, 1970). This is called the acrosome reaction. If eggs are introduced at the peak of sperm activation and the acrosome reaction, fertilization will take place quickly.

The relationship of sperm activation and acrosome reaction to capacitation is not clear at the present time. However, at least in the hamster, it seems that activation and the acrosome reaction occur either as final stages of capacitation (Yanagimachi, 1969a) or after the spermatozoa are completely capacitated. When spermatozoa show both activation and the acrosome reaction, they have probably completed the capacitation process and these parameters may, therefore, be used as visible indications that hamster spermatozoa have attained the capacitated state.

At present, a reliable chemically defined medium is not available for capacitating hamster spermatozoa in vitro. Bavister (1969) reported successful fertilization of hamster eggs in vitro, using a modified Tyrode's solution containing bovine serum albumin, sodium pyruvate and excess sodium bicarbonate (gas phase, $5 \% \mathrm{CO}_{2}$ in air), but we have not been able consistently to duplicate his success. The best results have been obtained by utilizing biological fluids, such as follicular fluid (Barros \& Austin, 1967; Gwatkin \& Andersen, 1969; Yanagimachi, 1969a, b) and blood serum (Barros \& Garavagno, 1970; Yanagimachi, $1970 \mathrm{a}, \mathrm{b})$. Even with these fluids, variations in results are almost the rule rather than the exception. Commercially available sera, in particular, produce highly varied results as Yanagimachi (1970b) has observed for hamster sperm capacitation. Furthermore, Boone, Mantel, Caruso, Kazam \& Stevenson (1972) have quantified many parameters of commercially available fetal calf serum and have established that great variation exists between different suppliers and even among samples. In an attempt to determine some of the causes of these variations and to determine some of the physical requirements for potential defined media, we have undertaken this study of the effects of osmolality and hydrogen ion concentration on activation and acrosome reaction of hamster spermatozoa in vitro.

Temperature is another environmental factor that is subject to variation. Mammalian spermatozoa are usually incubated at 37 to $38^{\circ} \mathrm{C}$ during experimentation in vitro, but are frequently subjected to temperature variations during the course of preparation. The temperature dependence of capacitation has not been quantified, and a study of temperature effects on sperm activation and acrosome reaction might provide clues to the nature of the capacitation process.

\section{MATERIALS AND METHODS}

The media used in this study were Tyrode's solution and $\gamma$-globulin-free human serum (agamma human serum, AGHS). A medium consisting of $50 \%$ AGHS 
(Hyland Laboratories) and 50\% Tyrode's solution produces consistent capacitation of hamster spermatozoa in vitro (Yanagimachi, 1970b). Spermatozoa from fertile male golden hamsters were obtained by puncturing the distal end of excised cauda epididymidis and gently expressing the contents. The spermatozoa were immediately suspended either in Tyrode's solution or in a mixture of $50 \%$ Tyrode's solution and $50 \%$ AGHS (the temperature was controlled at 23 to $37^{\circ} \mathrm{C}$ ).

\section{Temperature effects}

Spermatozoa were first allowed to disperse in Tyrode's solution at a concentration of 8 to $12 \times 10^{3}$ spermatozoa $/ \mu$, then $0.05 \mathrm{ml}$ of the suspension was thoroughly mixed with an equal volume of AGHS under mineral oil in a small watch-glass; the final preparations contained 4 to $6 \times 10^{3}$ spermatozoa $/ \mu$ l. For each experiment, one group of dishes thus prepared was incubated at $37^{\circ} \mathrm{G}$ (control) and one or two other groups were incubated simultaneously at different temperatures in different incubators (gas phase, air). Since three different incubators were used in these experiments, a control was run at $37^{\circ} \mathrm{C}$ in all three to rule out any possibility of differences being produced by the incubators instead of by the different temperatures. Hydrogen ion concentration was eliminated as an important variable by measuring a few dishes at varying temperatures at the start and end of incubation. Regardless of temperature, the $\mathrm{pH}$ values were within the range of $7 \cdot 2$ to $7 \cdot 8$. The temperatures studied ranged between 16 and $42^{\circ} \mathrm{C}$ with 2 to $3^{\circ} \mathrm{C}$ intervals (Tables 1 and 2). The spermatozoa were incubated at least until activation and the acrosome reaction reached maximum levels, or until the spermatozoa became moribund. Following preincubation for varying lengths of time at temperatures below $33^{\circ} \mathrm{G}$, some dishes were warmed to $37^{\circ} \mathrm{C}$ and compared with the unwarmed dishes.

\section{Osmotic pressure effects}

Tyrode's solutions with eight different osmolalities were prepared by two different methods. In the first method, only the concentration of $\mathrm{NaCl}$ was varied from $\frac{1}{4}$ to 2 times the concentration in ordinary (isosmotic) Tyrode's solution ( $8 \mathrm{~g} \mathrm{NaCl} /$ litre). In the other method, Tyrode's solution was prepared with all salts in twice the usual concentrations and with no glucose, then diluted with distilled water to produce the same osmolalities as in the first method (so that all the salts were present in the normal proportions). Glucose was then added at a concentration of $1 \mathrm{~g} /$ litre to all solutions; glucose has little effect on osmolality ( 5 mosmol) at this concentration. Each Tyrode's solution thus prepared or distilled water with $1 \mathrm{~g} /$ litre glucose was mixed with an equal volume of AGHS. The osmolality of a small portion of each mixture (Table 3) was determined using an osmometer (Osmette, Precision Systems). Spermatozoa were suspended in the remaining portion of each mixture at the concentration of 4 to $6 \times 10^{3}$ spermatozoa $/ \mu \mathrm{l}$, then $0 \cdot 1 \mathrm{ml}$ of each suspension was placed under mineral oil in a watch-glass. The preparations were incubated at $37^{\circ} \mathrm{C}$ for $4 \mathrm{hr}$ (gas phase, air). No significant differences in $\mathrm{pH}$ at the beginning or end of incubation were found in association with varying osmolalities. 


\section{pH effects}

The spermatozoa were suspended in ordinary Tyrode's solution $(\mathrm{pH} 7 \cdot 8$ to 7.9 ) at a concentration of 8 to $12 \times 10^{3}$ spermatozoa/ $\mu \mathrm{l}$, then $0.4 \mathrm{ml}$ of the suspension was mixed with an equal volume of AGHS ( $\mathrm{pH} 7.0$ to 7.3 ) in a plastic organ culture dish (Falcon Plastics) and immediately covered with mineral oil. The $\mathrm{pH}$ of the mixture in each dish was measured with a microelectrode and adjusted to the desired level (6.0 to 8.5, Table 4) with either $\frac{1}{7} \mathrm{~N}-\mathrm{NaOH}$ or $\frac{1}{7} \mathrm{~N}-\mathrm{HCl}$. The preparations were incubated for $4 \mathrm{hr}$ at $37^{\circ} \mathrm{G}$ (gas phase, air), then following the examination for activation and acrosome reaction, the final $\mathrm{pH}$ of each preparation was measured.

With the system used in the study, the $\mathrm{pH}$ values of the preparations did not stay constant except when the initial $\mathrm{pH}$ was about $7 \cdot 8$ (see Table 4 ). We have tested other gas phases, acids, bases and buffers (e.g. phosphate, citrate and tris buffers), but they either failed to hold the $\mathrm{pH}$ constant or, if they did so, had detrimental effects on the spermatozoa.

For studies of the effects of temperature, osmolality and $\mathrm{pH}$, the spermatozoa in each dish were examined periodically during incubation with a dark field microscope $(\times 60)$ and were rated according to the percentage of motile spermatozoa and the degree of their activation. The dishes were maintained close to the incubation temperature throughout the examination. The degree of sperm activation was rated 4 if more than $50 \%, 3$ if 30 to $50 \%, 2$ if 10 to $30 \%$, 1 if less than $10 \%$, and 0 if none of the motile spermatozoa showed activated movement. In some cases, the intermediate values such as 2.5 or 0.5 were used. After activation reached a maximum level (no improvement on subsequent examinations), the percentage of motile spermatozoa showing the acrosome reaction was determined by placing a small drop of the suspension between a slide and a coverslip and observing the spermatozoa with a phase-contrast microscope $(\times 400)$. Only the most actively motile spermatozoa, at least 50 to 100 in each count, were considered.

\section{RESULTS}

\section{Temperature effects}

In this paper, the activation time refers to the time at which the motility pattern of nearly all of the free-swimming spermatozoa changed to the pattern characteristic of activation. The spermatozoa usually began to break away from the agglutinations at variable times before the activation time and a few of these free spermatozoa showed activated movement, thus making the onset of activation rather difficult to assess accurately. At the activation time, on the other hand, the swimming behaviour of nearly all of the free-swimming spermatozoa changed markedly within a very few minutes so that the activation time could be accurately determined. After the activation time, increasing numbers of activated spermatozoa broke away from the agglutinations until a numerical peak or maximum was reached. The time at which this peak was reached was too variable to be useful.

Table 1 summarizes the effects of temperature on the activation time and the acrosome reaction. At the control temperature, $37^{\circ} \mathrm{G}$, the average activation 
Table 1. Effects of incubation temperature on the activation and acrosome reaction of hamster spermatozoa

\begin{tabular}{|c|c|c|c|c|c|}
\hline $\begin{array}{c}\text { Temp. } \\
\left({ }^{\circ} \mathrm{C}\right)\end{array}$ & $\begin{array}{c}\text { No. of } \\
\text { exps }\end{array}$ & $\begin{array}{l}\text { Average } \\
\text { activation } \\
\text { time } \\
(h r)\end{array}$ & $\begin{array}{c}\text { Best } \\
\text { activation } \\
\text { rating }\end{array}$ & $\begin{array}{c}\text { Approx. interval }(\mathrm{hr}) \\
\text { between activation } \\
\text { time and time of } \\
\text { maximum acrosome reaction }\end{array}$ & $\begin{array}{c}\text { Maximum \% } \\
\text { acrosome } \\
\text { reaction }\end{array}$ \\
\hline $\begin{array}{l}16 \\
20 \\
23 \\
25 \\
27 \\
29 \\
31 \\
33 \\
35 \\
37 \text { (control) } \\
40 \\
42\end{array}$ & $\begin{array}{l}3 \\
4 \\
3 \\
2 \\
3 \\
4 \\
3 \\
4 \\
2 \\
5 \\
3 \\
2\end{array}$ & $\begin{array}{l}\text { 二 }^{*} \\
\overline{12}^{*} \\
7 \frac{1}{2} \\
6 \\
41 \\
4 \\
3 \frac{1}{2} \\
3 \frac{1}{2} \\
2 \frac{3}{4} \\
2 \frac{1}{2} \\
2 \frac{3}{4}\end{array}$ & $\begin{array}{l}0 \\
0 \\
2 \\
3 \\
3 \\
4 \\
4 \\
4 \\
4 \\
4 \\
4 \\
1 \cdot 5\end{array}$ & $\begin{array}{l}\text { 二* } \\
5 \\
4 \\
4 \frac{3}{4} \\
2 \frac{1}{2} \\
2 \\
1 \frac{1}{2} \\
2 \\
1 \frac{3}{4} \\
1 \frac{1}{2} \\
1 \frac{8}{4} \\
1 \frac{1}{2}\end{array}$ & $\begin{array}{c}0 \\
0 \\
57 \cdot 1 \\
62 \cdot 8 \\
83 \cdot 6 \\
71 \cdot 4 \\
79 \cdot 3 \\
80 \cdot 4 \\
73 \cdot 1 \\
81 \cdot 8 \\
90 \cdot 0 \\
25 \cdot 0\end{array}$ \\
\hline
\end{tabular}

* No activation or acrosome reaction for up to $26 \mathrm{hr}$.

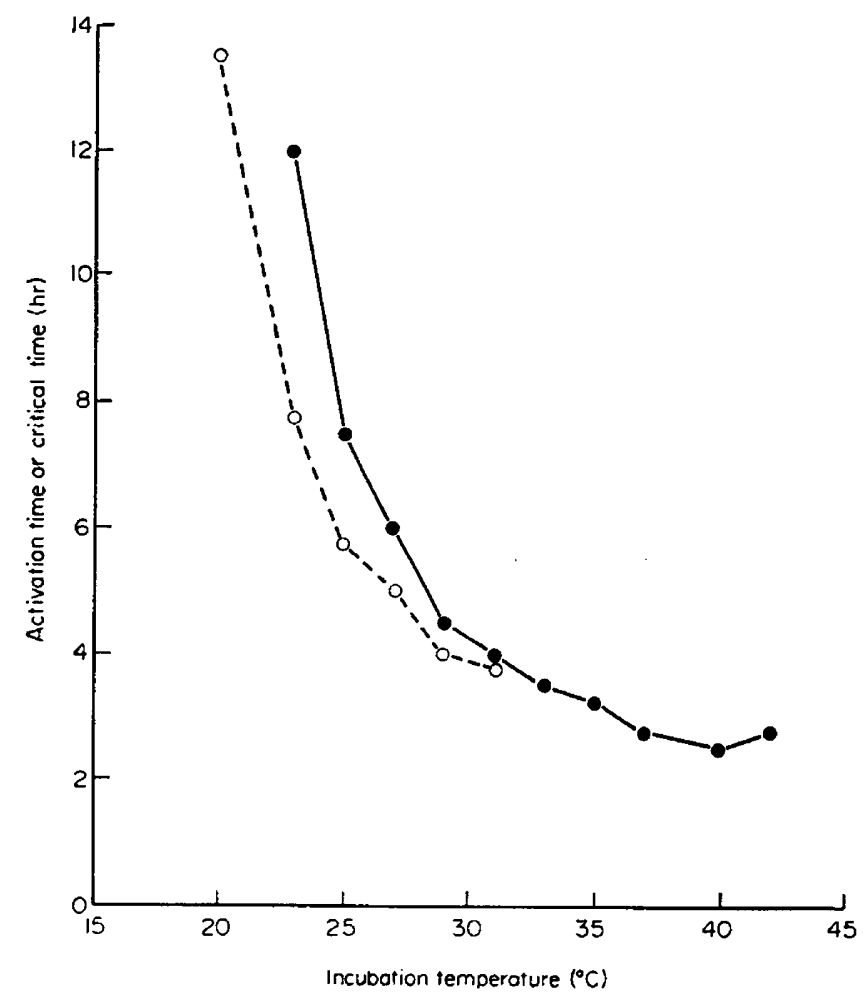

TEXT-Fig. 1. Effect of temperature on the activation time of hamster spermatozoa. - Activation times at various temperatures; $O$, critical times after which activation will occur within $15 \mathrm{~min}$ if spermatozoa are warmed to $37^{\circ} \mathrm{G}$. 
time was $2 \frac{3}{4} \mathrm{hr}$ after the start of incubation. This was only $15 \mathrm{~min}$ later than the earliest activation time of $2 \frac{1}{2} \mathrm{hr}$ at $40^{\circ} \mathrm{C}$. When the incubation temperature was $42^{\circ} \mathrm{C}$, the time required for activation was about the same as that of the control, but activation, acrosome reaction and survival rates were low. Spermatozoa incubated at temperatures between 40 and $29^{\circ} \mathrm{C}$ required gradually increasing times for activation as lower temperatures were used. Below $29^{\circ} \mathrm{C}$, the activation time increased rapidly (solid line of Text-fig. 1). The lowest temperature at which any activation occurred spontaneously was $23^{\circ} \mathrm{C}$. When activation occurred, it usually had good ratings of 3 to 4 , except at $23^{\circ} \mathrm{C}$.

The survival rate was at least $50 \%$ at the activation time at all but the highest temperature $\left(42^{\circ} \mathrm{G}\right)$ studied. Even at $16^{\circ} \mathrm{C}$ after $26 \mathrm{hr}$, the percentage of motile spermatozoa was about $50 \%$ although morbidity was evident by that time. In most cases, the percentage of motile spermatozoa showing the acro-

Table 2. Activation and acrosome reaction of hamster spermatozoa at $37^{\circ} \mathrm{C}$ following preincubation at various low temperatures

\begin{tabular}{c|c|c|c|c|c}
\hline \multicolumn{3}{c|}{ Preincubation } & \multicolumn{4}{|c}{ Postincubation at $37^{\circ} \mathrm{C}$} \\
\hline $\begin{array}{c}\text { Temp. } \\
\left({ }^{\circ} \mathrm{C}\right)\end{array}$ & $\begin{array}{c}\text { No. of } \\
\text { exps }\end{array}$ & $\begin{array}{c}\text { Critical } \\
\text { time* } \\
(\text { average }) \\
(\mathrm{hr})\end{array}$ & $\begin{array}{c}\text { Best activation } \\
\text { rating }\end{array}$ & $\begin{array}{c}\text { Approx. time }(\mathrm{hr}) \\
\text { required for } \\
\text { maximum acrosome } \\
\text { reaction }\end{array}$ & $\begin{array}{c}\text { Maximum } \% \\
\text { acrosome } \\
\text { reaction }\end{array}$ \\
\hline 16 & 3 & - & 0 & - & 0 \\
20 & 5 & $13 \frac{1}{2}$ & 2 & 3 & $87 \cdot 8$ \\
23 & 3 & 7 & 3 & $84 \cdot 6$ \\
25 & 2 & 5 & 4 & 3 & $60 \cdot 8$ \\
27 & 3 & 5 & 4 & 3 & $66 \cdot 0$ \\
29 & 3 & 4 & 4 & 3 & $75 \cdot 8$ \\
31 & 2 & 3 & 4 & 3 & $70 \cdot 5$ \\
\hline
\end{tabular}

* The minimum preincubation time after which spermatozoa undergo activation within $15 \mathrm{~min}$ at $37^{\circ} \mathrm{C}$.

$\dagger$ Spermatozoa would not activate within $15 \mathrm{~min}$ at $37^{\circ} \mathrm{C}$, even after preincubation for 17 to $26 \mathrm{hr}$.

some reaction was $50 \%$ or more. Sometimes, a very few spermatozoa showed acrosome reactions at the activation time, but the acrosome reaction did not involve a maximum number of spermatozoa until considerably later. At temperatures between 42 and $31^{\circ} \mathrm{C}$, this lag was $1 \frac{1}{4}$ to $1 \frac{3}{4} \mathrm{hr}$ and below $31^{\circ} \mathrm{C}$, the lag increased with lower temperatures.

It was found that when spermatozoa were preincubated at temperatures below $33^{\circ} \mathrm{C}$ beyond a critical length of time, they could be activated almost instantly by warming to $37^{\circ} \mathrm{C}$. The 'critical times' (Table 2 and broken line in Text-fig. 1) were considerably less than the times required for activation without warming to $37^{\circ} \mathrm{C}$ (Table 1 and solid line of Text-fig. 1). Activation could be induced in this manner even following incubation at $20^{\circ} \mathrm{C}$ where it was not possible otherwise, but the activation did not have good ratings following preincubation at this temperature. At $16^{\circ} \mathrm{C}$, activation could not be induced instantly by warming regardless of the preincubation time. In suspensions warmed to $37^{\circ} \mathrm{C}$ after preincubation at 31 to $20^{\circ} \mathrm{C}$, the acrosome reaction usually reached its maximum level approximately $3 \mathrm{hr}$ after the critical time. 
Osmotic pressure effect

The data obtained revealed that the method of altering the osmotic pressure of the medium (cf. Materials and Methods section) made little or no difference in the results of the experiments; all the data are therefore combined here. The results (Table 3 ) show that spermatozoa can well tolerate and activate with acrosome reactions of $50 \%$ or more in media with osmolalities ranging from 230 to 343 mosmol. At the lower limit of this range (230 mosmol), activation usually involved a large number of the motile spermatozoa but did not appear entirely normal. Many of the spermatozoa moved very rapidly but only briefly exhibited the extreme flexing of the flagella characteristic of activated movement (Yanagimachi, 1970a), then swam more linearly for a short distance before again briefly showing the characteristic activation

Table 3. Effects of the osmotic pressure of the incubation medium on the activation, acrosome reaction and survival of hamster spermatozoa examined $4 \mathrm{hr}$ after the start of incubation at $37^{\circ} \mathrm{G}$

\begin{tabular}{|c|c|c|c|c|c|c|c|}
\hline \multirow{2}{*}{$\begin{array}{l}\text { Osmotic pressure of } \\
\text { incubation medium } \\
\text { (mosmol) }\end{array}$} & \multirow{2}{*}{$\begin{array}{l}\text { No. of } \\
\text { exps }\end{array}$} & \multicolumn{2}{|c|}{ Activation rating } & \multicolumn{2}{|c|}{$\%$ acrosome reaction } & \multicolumn{2}{|c|}{$\%$ motile spermatozoa } \\
\hline & & Average & (Range) & Average & (Range) & Average & (Range) \\
\hline $\begin{array}{l}193 \\
230 \\
268 \\
304 \\
343 \\
367 \\
404 \\
439 \\
470\end{array}$ & $\begin{array}{l}3 \\
5 \\
6 \\
2 \\
4 \\
2 \\
2 \\
4 \\
4\end{array}$ & $\begin{array}{l}0 \\
2 \cdot 1 \\
3 \cdot 3 \\
2 \cdot 5 \\
3 \cdot 4 \\
1 \cdot 5 \\
1 \cdot 0 \\
0 \cdot 3 \\
0\end{array}$ & 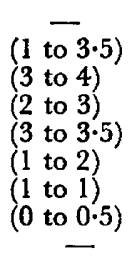 & $\begin{array}{l}21 \cdot 6^{*} \\
42 \cdot 5 \\
45 \cdot 1 \\
59 \cdot 7 \\
67 \cdot 7 \\
63 \cdot 7 \\
24 \cdot 3 \\
0 \\
0\end{array}$ & $\begin{array}{c}(14 \text { to } 34)^{*} \\
(24 \text { to } 52) \\
(38 \text { to } 59) \\
(40 \text { to } 79) \\
(49 \text { to } 81) \\
(63 \text { to } 65) \\
(18 \text { to } 31) \\
\text { - }\end{array}$ & $\begin{array}{r}43 \cdot 3 \\
40 \cdot 0 \\
38 \cdot 3 \\
35 \cdot 0 \\
45 \cdot 0 \\
30 \cdot 0 \\
30 \cdot 0 \\
8 \cdot 3 \\
7 \cdot 0\end{array}$ & $\begin{array}{l}(30 \text { to } 50) \\
(35 \text { to } 45) \\
(30 \text { to } 50) \\
(30 \text { to } 40) \\
(40 \text { to } 50) \\
(30 \text { to } 30) \\
(30 \text { to } 30) \\
(3 \text { to } 10) \\
(3 \text { to } 10)\end{array}$ \\
\hline
\end{tabular}

* Probably moribund changes rather than a true physiological acrosome reaction. The tails of these spermatozoa were sharply bent.

movements. In the most dilute medium (193 mosmol), activation did not occur and the swimming behaviour of most of the spermatozoa was abnormal. The flagella of many of the freely swimming spermatozoa were sharply bent back on themselves, giving them the appearance of hairpins. In media with osmotic pressures greater than 400 mosmol, most of the spermatozoa quickly became moribund but a very few did show activation. At 439 mosmol, for instance, only 1 in 1000 spermatozoa appeared to be activated; the rest of the live spermatozoa were barely motile.

\section{pH effects}

The results of experiments with altered $\mathrm{pH}$ are presented in Table 4. It can be seen that spermatozoa will activate well in incubation media having initial $\mathrm{pH}$ values of 7.0 to 8.25 with no clearly defined optimum. Some activation occurred even when the initial $\mathrm{pH}$ was 6.5 or 8.45 . At the lower levels $(6.0$ to $6 \cdot 5)$, however, the $\mathrm{pH}$ increased rapidly almost to $\mathrm{pH} \mathrm{7.0.} \mathrm{The} \mathrm{higher} \mathrm{pH}$ values $(8.0$ and 8.6$)$ were likewise unstable, falling slowly during incubation to about 7.8 or 8.0 , respectively. More than $50 \%$ of the motile spermatozoa showed acrosome reactions when the initial $\mathrm{pH}$ values were $7 \cdot 2$ to $8 \cdot 25$. Survival 


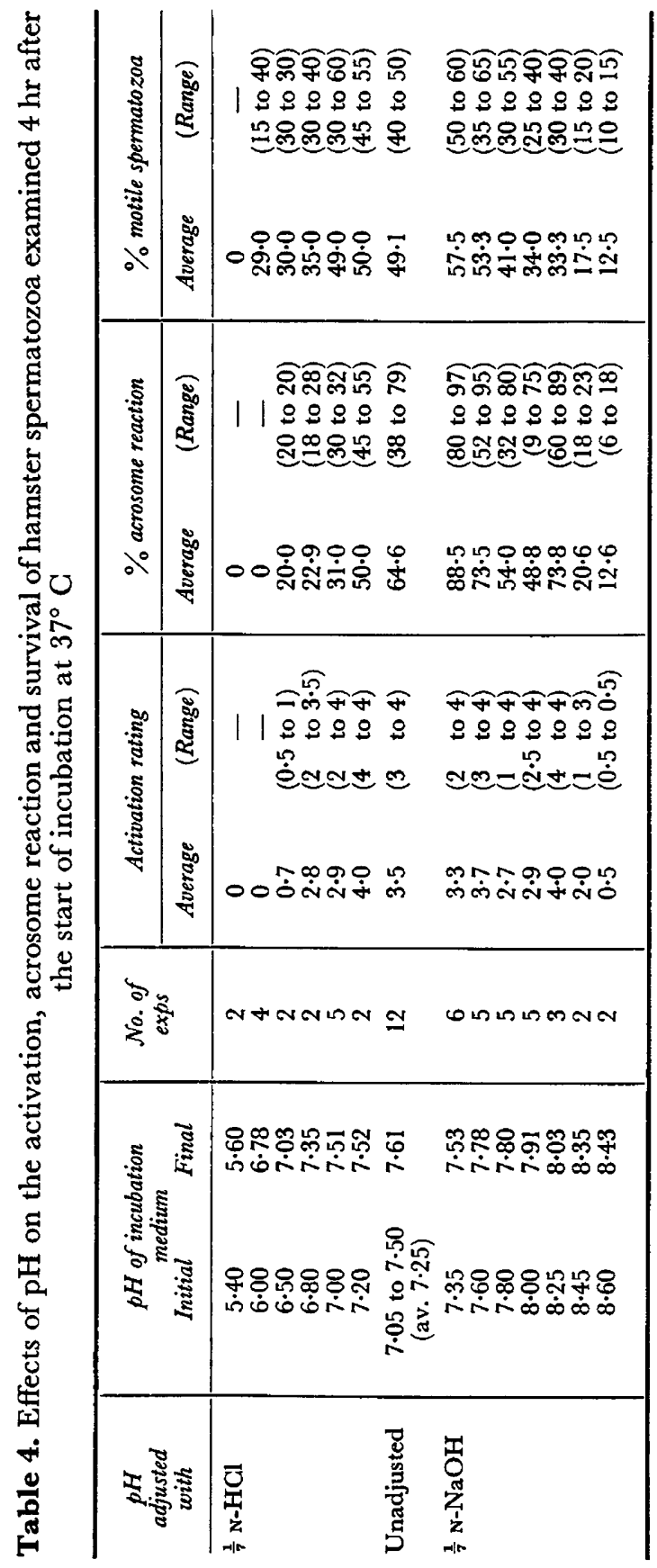


of spermatozoa was impaired when the initial $\mathrm{pH}$ was lower than 7.0 or higher than $7 \cdot 8$.

\section{DISCUSSION}

\section{Temperature effects}

Under the experimental conditions used in this study, an incubation temperature of $42^{\circ} \mathrm{C}$ is unfavourable for the survival of hamster spermatozoa. Nelson (1967) states that high temperatures cause enzyme denaturation and mature spermatozoa cannot regenerate enzymes. Temperature variations between 40 and $16^{\circ} \mathrm{C}$ did not have significant effects on sperm survival within the periods of time involved in our experiments, but did have definite effects on sperm activation and acrosome reaction. For instance: (1) spermatozoa underwent neither activation nor acrosome reaction at $16^{\circ} \mathrm{C}$; (2) at $25^{\circ} \mathrm{C}$, both activation and acrosome reaction took place, but the latter was greatly delayed; (3) at $37^{\circ} \mathrm{C}$, the acrosome reaction reached a maximum level about $1 \frac{1}{2} \mathrm{hr}$ after the time of activation; (4) spermatozoa could be activated almost instantly by warming them to $37^{\circ} \mathrm{C}$ after preincubation at 31 to $23^{\circ} \mathrm{C}$ beyond critical periods of time and, under these conditions, the largest numbers of spermatozoa showed acrosome reactions approximately $3 \mathrm{hr}$ after activation; (5) activation never occurred at $20^{\circ} \mathrm{C}$, but it did take place instantly when the suspensions were warmed to $37^{\circ} \mathrm{C}$ following $13 \frac{1}{2} \mathrm{hr}$ incubation at $20^{\circ} \mathrm{C}$.

These facts, especially the fourth point, suggest that at least three processes with different degrees of temperature-dependence are involved in sperm activation and the acrosome reaction. The first process is a preparatory phase for activation and the acrosome reaction and perhaps involves the membrane changes suggested by Bedford (1970) and Ericsson \& Buthala (1970), and the metabolic changes suggested by Hamner (1970) and Bishop (1971). The rate at which this process is completed is dependent on temperature (e.g. $2 \frac{3}{4} \mathrm{hr}$ at $37^{\circ} \mathrm{C}, 13 \frac{1}{2} \mathrm{hr}$ at $20^{\circ} \mathrm{C}$ ). The second process is the actual activation of the spermatozoa. This process is initiated by the completion of the first process. It proceeds quickly at 31 to $40^{\circ} \mathrm{C}$ and is not significantly affected by temperature variations within this range; below $31^{\circ} \mathrm{C}$, however, this process is temperature-dependent. The acrosome reaction is the end result of the third process. The pattern of temperature-dependence of the third process is very similar to that of the second process, indicating a possible relationship. The exact nature of such a relationship is not clear, but the third process may possibly be a continuation of the second or may simply respond to temperature variations in a similar manner. At $31^{\circ} \mathrm{C}$ and at $29^{\circ} \mathrm{C}$, the total time required (from the start of incubation) for the acrosome reaction to reach a maximum level was greater if the spermatozoa were warmed to $37^{\circ} \mathrm{C}$ than if they were left continuously at the preincubation temperature. This may be due to some delaying effect on the third process brought about by the rather sudden increase in temperature. It is not clear whether the acrosome reaction depends on the first two processes, but this seems to be the case since we have not been able so far to achieve a physiological acrosome reaction in unactivated spermatozoa.

The solid line in Text-fig. 1 is determined by both the first and the second processes. The slope of the line between 31 and $40^{\circ} \mathrm{C}$ is dependent on the first 
process and the slope for temperatures below $31^{\circ} \mathrm{C}$, as well as the minimum temperature on this line, is determined by the second process. The critical times plotted in the broken line of Text-fig. 1 and the minimum temperature on this line are determined by the first process. Text-figure 1 and Tables 1 and 2 indicate that the first process is inactivated below $20^{\circ} \mathrm{C}$ and the second process is inactivated at temperatures below $23^{\circ} \mathrm{C}$.

With respect to temperature, activation and acrosome reaction appear to be 'all-or-none' responses. Since incubation temperatures had little effect on final maximum rates of activation or acrosome reaction, temperature effects can be useful. For instance, spermatozoa can be stored at $23^{\circ} \mathrm{G}$ for several hours then warmed to $37^{\circ} \mathrm{C}$ for use. When studies require the separation, in time, of activation from the acrosome reaction, temperatures of about $27^{\circ} \mathrm{C}$ can be used.

The reduced speed of sperm movement at lower temperatures was predictable. Richards (1963) carefully measured an obvious decrease in the locomotion rate of cockroach spermatozoa as a function of temperature.

\section{Osmotic pressure effects}

Before effecting fertilization, mammalian spermatozoa are exposed to the fluids of the male accessory glands as well as the fluids of the female genital tract. According to Rothschild \& Barnes (1954), bull seminal plasma has a mean freezing point depression of $-0.53^{\circ} \mathrm{C}(\simeq 295 \mathrm{mosmol})$. The osmolalities of the uterine, oviducal and follicular fluids of the cow are 353, 350 and 287 mosmol, respectively (Olds \& VanDemark, 1957). In the rabbit, semen has a freezing point depression of -0.55 to $-0.59^{\circ} \mathrm{C}$ (Mann, 1964; $\simeq 295$ to 320 mosmol) and oviducal fluid has an osmolality of about 375 mosmol (Hamner \& Fox, 1969). Thus, mammalian spermatozoa are probably subjected to variations in osmotic pressures during their ascent through the female genital tract and a tolerance to variable osmotic pressures would be expected. Chang \& Thorsteinsson (1958) found that rabbit spermatozoa would recover normal motility when returned to normal osmolality following brief (10 to $20 \mathrm{~min}$ ) exposures to osmotic pressures as low as about $60 \mathrm{mosmol}$ and as high as about 600 mosmol. In the present study, the range of osmotic pressures was not nearly so great (193 to $470 \mathrm{mosmol}$ ), but the spermatozoa were exposed for the entire incubation period of $4 \mathrm{hr}$. The data show that hamster spermatozoa maintained their motility over a fairly wide range of osmolality (193 to $343 \mathrm{mosmol}$ ), but activation and the acrosome reaction occurred best within a somewhat narrower range ( 268 to 343 mosmol).

As in the bull (Drevius, 1963; O'Donnell, 1972), rabbit and human (Drevius, 1963), a very hypotonic (193 mosmol) solution was detrimental to hamster spermatozoa as shown by the frequent occurrence of sharply bent flagella. The greatly reduced motility (both percentage and swimming rate) in hypertonic media (439 to $470 \mathrm{mosmol}$ ) was also reported by O'Donnell (1972) for bull spermatozoa.

pH effects

A number of experiments have probed the effects of hydrogen ion concen- 
tration on the motility, viability and metabolism of the spermatozoa of various mammalian species (Mann, 1964). Most authors agree that a nearly neutral $\mathrm{pH}$ is optimal for the survival of most mammalian spermatozoa (Mann, 1964). According to Emmens (1947), rabbit spermatozoa retain partial motility for several hours at $\mathrm{pH} 9.5$ to 10.0 whereas at $\mathrm{pH}$ values below 5.8 , they become immotile and die rapidly. Chang \& Thorsteinsson (1958) reported that a brief (10 to $20 \mathrm{~min}$ ) exposure of rabbit spermatozoa to isotonic media with $\mathrm{pH}$ values as high as $9 \cdot 0$ to $10 \cdot 2$, or as low as $5 \cdot 6$, affected neither the motility nor the fertilizing capacity of the spermatozoa. At higher or lower $\mathrm{pH}$ values, both motility and fertilizing capacity diminished rapidly.

Our experiments with golden hamster spermatozoa reveal that good survival, activation and acrosome reaction occur within a range of $\mathrm{pH} 7 \cdot 2$ to $7 \cdot 8$. Lower or higher $\mathrm{pH}$ values are detrimental to one or more of these parameters. For example, at $\mathrm{pH} 8.25$, both activation and the acrosome reaction, which we used as indications of capacitation, were good, but the survival rate was poor. Thus, it appears that, outside the range of $7 \cdot 2$ to $7 \cdot 8$, each of the three parameters has a different optimum $\mathrm{pH}$ range.

Gregg (1971) found that under defined conditions of sperm numbers, calcium concentration and 'fertilizin' stimulation, there is a clearly defined $\mathrm{pH}$ optimum of 8.0 for a maximal acrosome reaction in Arbacia punctulata spermatozoa. In Arbacia, fertilization occurs in sea water which has a $\mathrm{pH}$ of about 8.0. In mammals, fertilization takes place in the oviducts of oestrous females. Oviduct fluids have $\mathrm{pH}$ values of 8.04 for the rat (Blandau, Jensen \& Rumery, 1958), $6 \cdot 8$ to $7 \cdot 0$ for the sheep and $7 \cdot 75$ to 8.0 for the rabbit (Bishop, 1957; Vishwakarma, 1962; Hamner \& Fox, 1969). Although no data are available for the $\mathrm{pH}$ of the oviduct fluids of oestrous hamsters, the $\mathrm{pH}$ is probably well within the range of $7 \cdot 2$ to $8 \cdot 2$, which is most favourable for activation and acrosome reaction in vitro. Bavister (1969) achieved the highest incidence of fertilization of hamster eggs in vitro in his medium with $\mathrm{pH}$ values of 7.6 to $7 \cdot 8$. This narrower range of optimum $\mathrm{pH}$ for fertilization is to be expected since fertilization is the end result of a series of interactions between the spermatozoon and egg and each stage of the series could have a different $\mathrm{pH}$ optimum.

\section{AGKNOWLEDGMENTS}

This study was supported by grants from NIH-USPHS (HD-03402), the Population Council and the Ford Foundation. The authors are grateful to Dr R. J. Teichman and Dr B. F. Lino for their assistance in the preparation of the manuscript.

\section{REFERENGES}

BarRos, C. \& Austin, C. R. (1967) In vitro fertilization and the sperm acrosome reaction in the hamster. F. exp. Zool. 166, 317.

Barros, G. \& Garavagno, A. (1970) Capacitation of hamster spermatozoa with blood sera. F. Reprod. Fert. 22, 381.

BAvister, B. D. (1969) Environmental factors important for in vitro fertilization in the hamster. $\mathcal{F}$. Reprod. Fert. 18, 544. 
BEDFORD, J. M. (1970) Morphological aspects of capacitation in mammals. In: Advances in Biosciences, Vol. 4. Schering Symposium on Mechanisms Involved in Conception, Berlin, 1969. Ed. G. Raspé. Pergamon Press, New York.

Bishop, D. W. (1957) Metabolic conditions within the oviduct of the rabbit. Int. F. Fert. 2, 11.

Bishop, D. W. (1971) Sperm transport in the Fallopian tube. In: Pathways to Conception. Ed. A. I. Sherman. Charles C. Thomas, Springfield, Illinois.

Blandau, R., Jensen, L. \& Rumery, R. (1958) Determination of the pH values of the reproductivetract fluids of the rat during heat. Fert. Steril. 9, 207.

Boone, G. W., Mantel, N., Caruso, T. D., Kazam, E. \& Stevenson, R. E. (1972) Quality control studies on fetal bovine serum used in tissue culture. In Vitro, 7, 174.

Chang, M. G. \& Thorsteinsson, T. (1958) Effects of osmotic pressure and hydrogen-ion concentration on the motility and fertilizing capacity of rabbit spermatozoa. Fert. Steril. 9, 510.

Drevius, L. O. (1963) Spiralization in tails of mammalian spermatozoa in hypotonic media. Nature, Lond. 197, 1123.

Emmens, C. W. (1947) The motility and viability of rabbit spermatozoa at different hydrogen-ion concentrations. F. Physiol., Lond. 106, 471.

ERICsson, R. J. \& Buthala, D. A. (1970) A fluorescence staining method for studying sperm membranes. Biol. Reprod. 3, 8.

GREGG, K. W. (1971) A study of cortical response antigens, egg jelly and the induction of the acrosome reaction using gametes of the sea urchin, Arbacia punctulata. Ph.D. dissertation, University of Miami, Coral Gables, Florida.

Gwatkin, R. B. L. \& Andersen, O. F. (1969) Capacitation of hamster spermatozoa by bovine follicular fluid. Nature, Lond. 224, 1111.

HAMneR, C. E. (1970) The semen. In: Reproductive and Breeding Techniques for Laboratory Animals. Ed. E. S. E. Hafez. Lea \& Febiger, Philadelphia.

HAMner, C. E. \& Fox, S. B. (1969) Biochemistry of oviductal secretions. In: The Mammalian Oviduct. Eds. E. S. E. Hafez and R. J. Blandau. University of Chicago Press, Chicago.

Mann, T. (1964) The biochemistry of semen and of the male reproductive tract. Wiley, New York.

Nelson, L. (1967) Sperm motility. In: Fertilization, Vol. 1. Eds. C. B. Metz and A. Monroy. Academic Press, New York.

O'Donnelt, J. M. (1972) Behaviour of bovine spermatozoa in media of varying osmolality and tonicity. Expl Cell Res. 71, 297.

Olds, D. \& VanDemark, N. L. (1957) Composition of luminal fluids in bovine female genitalia. Fert. Steril. 8, 345.

Richards, A. G. (1963) The rate of sperm locomotion in the cockroach (Periplaneta americana) as a function of temperature. F. Insect Physiol. 9, 545.

Rothschild, Lord \& BARNes, H. (1954) Osmotic pressure of bull semen diluents. Nature, Lond. 173, 636.

Vishwakarma, P. (1962) The $\mathrm{pH}$ and bicarbonate-ion content of the oviduct and uterine fluids. Fert. Steril. 13, 481.

YANAGMACHI, R. (1969a) In vitro capacitation of hamster spermatozoa by follicular fluid. $\mathcal{F}$. Reprod. Fert. 18, 275.

YANAGMACHI, R. (1969b) In vitro acrosome reaction and capacitation of golden hamster spermatozoa by bovine follicular fluid and its fractions. F. exp. Zool. 170, 269.

YANAGIMACHI, R. (1970a) The movement of golden hamster spermatozoa before and after capacitation. 7. Reprod. Fert. 23, 193.

YANAGIMACHI, R. (1970b) In vitro capacitation of golden hamster spermatozoa by homologous and heterologous blood sera. Biol. Reprod. 3, 147.

Yanagimachi, R. \& Noda, Y. D. (1970) Fine structure of the hamster sperm head. Am. F. Anat. 128, 367. 